Chemical Destruction of HMX-Based

Explosives with Ammonium Hydroxide

Cary Skidmore

Philip Dell'Orco

Raymond Flesner

John Kramer

Terry Spontarelli 


\section{DISCLAIMER}

Portions of this document may be illegible in electronic image products. Images are produced from the best available original document. 


\section{CONTENTS}

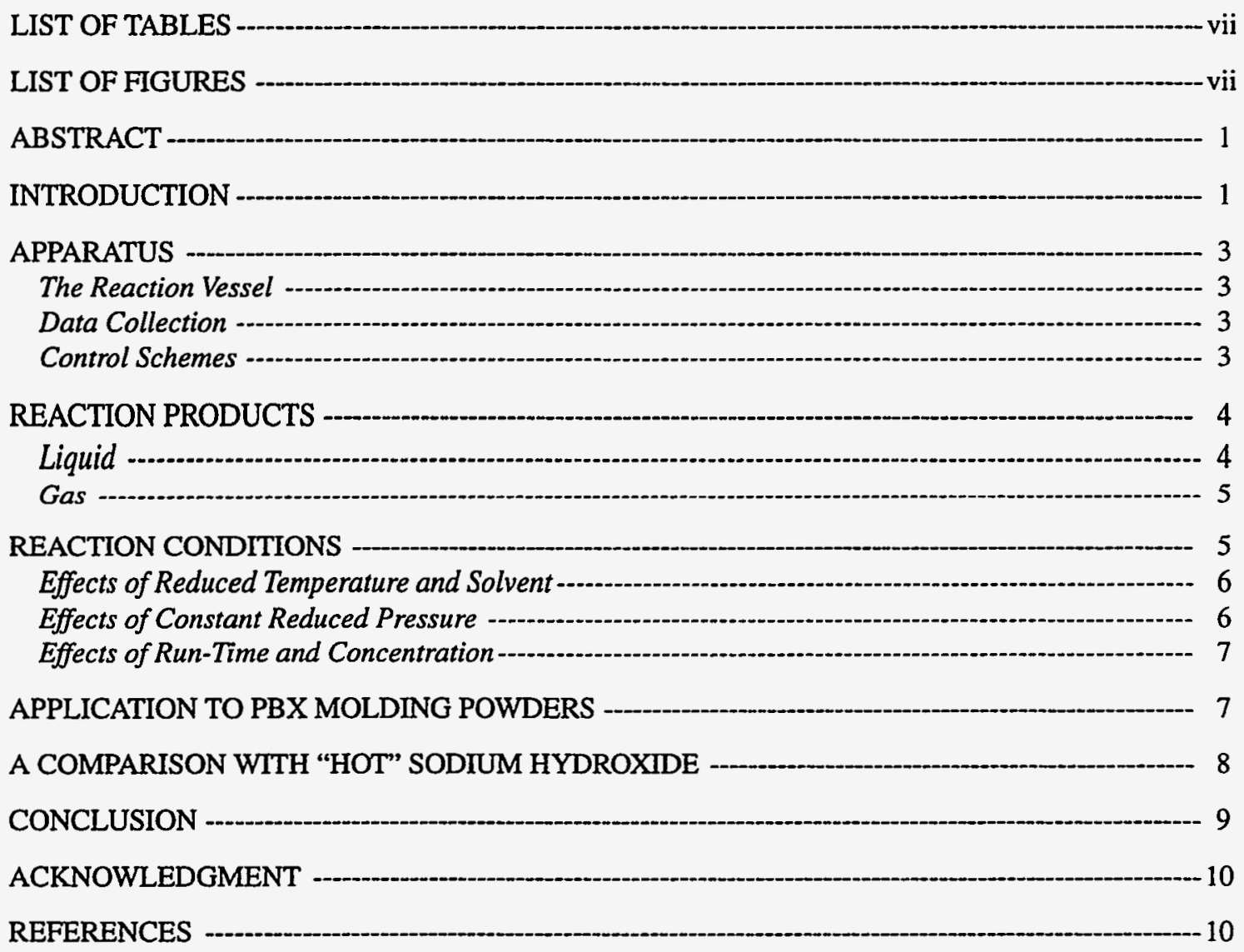




\section{LIST OF TABLES}

Table 1. Particle-Size Distribution of HMX-C, Lot HOL83 L030-050,

Determined by Sieve Analysis -..- 2

Table 2. Summary of Experiments -_- 2

Table 3. Ion Chromatography and Carbon Analysis Results -.......... 4

Table 4. Gas Chromatography Results -.-..- 5

Table 5. Molding Powder Compositions --..- 7

Table 6. Summary of Experiments with PBX Molding Powders -ב- 7

Table 7. Summary of Experiments to Evaluate $\mathrm{NaOH}$ at Elevated Temperature-_-_-_-_- 9

\section{LIST OF FIGURES}

Figure 1. Chronogram without cooling water in the control loop (CAH01) --_-_-_- 11

Figure 2. Chronogram with cooling water in the control loop (CAH28)

Figure 3. Chronogram of experiment CAH05

Figure 4. A "blank" compared with several reaction experiments -...__-_ 12

Figure 5. Chronogram of baseline ammonium hydroxide experiment (CAH30) -._-_..-- 13

Figure 6. Chronogram of baseline sodium hydroxide experiment (CAH32) -.._-_...-...- 13

Figure 7. Chronogram of $6 \mathrm{M}$ sodium hydroxide experiment (CAH33) -.-.-.-.-14

Figure 8. Chronogram of PBX 9404 molding powder experiment (CAH34) -

Figure 9. Chronogram of LX-04 molding powder experiment (CAH36)

Figure 10. Chronogram of PBX 9404 consolidated piece experiment (CAH35) -...-......- 15

Figure 11. Chronogram of $15 \mathrm{M}$ ammonium hydroxide experiment (CAH22) --.---.---.---- 16 


\title{
CHEMICAL DESTRUCTION OF HMX-BASED EXPLOSIVES WITH AMMONIUM HYDROXIDE
}

\author{
by \\ Cary Skidmore, Philip Dell'Orco, Raymond Flesner, \\ John Kramer, and Terry Spontarelli
}

\begin{abstract}
A series of experiments at Los Alamos National Laboratory explored the efficacy of ammonium hydroxide solutions in converting HMX (cyclotetramethylene-tetranitramine, or Octogen) and HMX-based explosives to nonenergetic, nonhazardous materials. When $80 \mathrm{~g}$ of explosive was converted in a reactor operating at $85 \mathrm{psig}$ pressure at $140^{\circ} \mathrm{C}$, the principal gaseous products were nitrous oxide (46\% to $51 \%$ ), nitrogen (22\% to $32 \%$ ), and ammonia (17\% to $28 \%$ ). Formate and hexamethylenetetramine (hexamine) account for effectively $100 \%$ of the carbon-bearing aqueous species. Nitrate, nitrite, and acetate were present in the liquid in trace amounts. The process effectively treated molding powders of the plastic-bonded explosives PBX 9501 (2.5\% estane), LX-04 (15\% viton), and PBX 9404 (3\% nitrocellulose). Results were compared with those achieved using sodium hydroxide solutions at $150^{\circ} \mathrm{C}$ in a pressurized reactor.
\end{abstract}

\section{INTRODUCTION}

When treated with a basic solution of sodium hydroxide, many energetic materials (explosives) decompose into water-soluble, nonenergetic materials. Studies using ammonium hydroxide as a basic solution for converting up to $\mathbf{3} \mathrm{g}$ of explosive indicated that such a conversion is feasible at elevated temperatures in a pressure vessel and that the resulting product stream is less complex than the product stream from a sodium hydroxide solution. ${ }^{1}$ Described here are the engineering aspects of using this process to convert up to $80 \mathrm{~g}$ of explosive.

We chose HMX (cyclotetramethylene-tetranitramine, or Octogen) and HMX-based formulations as the explosive materials. The HMX was a coarse powder designated Grade $C$ (see Table 1 for particle-size distributions), and the HMX formulations were in the molding powder form. We also conducted a few experiments with consolidated pieces; these experiments are explicitly identified.

Spontarelli previously established $1.5 \mathrm{M}$ as the optimum concentration of sodium hydroxide for an open system (ambient pressure) process with $10 \mathrm{~mL}$ of base for every gram of explosive. ${ }^{2}$

Similar values were used successfully in the earlier ammonium hydroxide experiments. For these reasons, we adopted similar values for the ammonium hydroxide experiments described here and summarized in Table 2. Experiments in this series are designated CAHO1 through CAH37. When the narrative refers to the results of a specific experiment, the designation appears in parentheses. 
Table 1. Particle-Size Distribution of HMX-C, Lot HOL83 L030-050, Determined by Sieve Analysis

\begin{tabular}{|c|c|c|c|}
\hline $\begin{array}{c}\text { Total } \\
\text { Retained } \\
(\mathbf{w t} \%)\end{array}$ & $\begin{array}{c}\text { Cumulative } \\
\text { Retained } \\
(\mathbf{w t} \%)\end{array}$ & $\begin{array}{c}\text { Minimum Particle } \\
\text { Diameter } \\
(\mu \mathrm{m})\end{array}$ & $\begin{array}{c}\text { Maximum Particle } \\
\text { Diameter } \\
(\mu \mathrm{m})\end{array}$ \\
\hline 0.9 & 0.9 & 500 & $>500$ \\
\hline 3.3 & 4.2 & 350 & $<500$ \\
\hline 7.7 & 11.8 & 250 & $<350$ \\
\hline 21.3 & 33 & 177 & $<250$ \\
\hline 27 & 60 & 125 & $<177$ \\
\hline 16 & 76 & 88 & $<125$ \\
\hline 12.4 & 88.4 & 62 & $<88$ \\
\hline 4.4 & 93.8 & 44 & $<62$ \\
\hline 4.2 & 97 & 30 & $<44$ \\
\hline 1.2 & 98.2 & 20 & $<30$ \\
\hline & & & \\
\hline
\end{tabular}

Table 2. Summary of Experiments

\begin{tabular}{|c|c|c|c|c|}
\hline Experiment & Explosive Type & $\begin{array}{l}\text { Explosive Weight } \\
\text { (g) }\end{array}$ & $\begin{array}{c}\text { Base } \\
\text { Concentration } \\
\text { and Type }\end{array}$ & $\begin{array}{c}\text { Base Volume } \\
(\mathrm{mL})\end{array}$ \\
\hline СAH01 & $\mathrm{HMX}-\mathrm{C}$ & 40 & $1.5 \mathrm{M} \mathrm{NH}_{4} \mathrm{OH}$ & 400 \\
\hline CAH02 & HMX-C & 20 & $15 \mathrm{M} \mathrm{NH}_{4} \mathrm{OH}$ & 400 \\
\hline CAH03 & HMX-C & 20 & $1.5 \mathrm{M} \mathrm{NH}_{4} \mathrm{OH}$ & 200 \\
\hline CAHO4 & HMX-C & 20 & $15 \mathrm{M} \mathrm{NH}_{4} \mathrm{OH}$ & 200 \\
\hline CAH05 & HMX-C & 80 & $1.5 \mathrm{M} \mathrm{NH}_{4} \mathrm{OH}$ & 800 \\
\hline САH06 & $\mathrm{HMX}-\mathrm{C}$ & 20 & $1.5 \mathrm{M} \mathrm{NH}_{4} \mathrm{OH}$ & 200 \\
\hline CAH07 & CAH06 cont'd & NA & NA & $\mathrm{NA}$ \\
\hline CAH11 & HMX-C & 20 & $1.5 \mathrm{M} \mathrm{NH}_{4} \mathrm{OH}$ & 200 \\
\hline $\mathrm{CAH} 17$ & HMX-C & 40 & $1.5 \mathrm{M} \mathrm{NH}_{4} \mathrm{OH}$ & 400 \\
\hline $\mathrm{CAH} 20$ & none & 0 & $1.5 \mathrm{M} \mathrm{NH}_{4} \mathrm{OH}$ & 400 \\
\hline CAH21 & PBX 9404 & 40 & $1.5 \mathrm{M} \mathrm{NH}_{4} \mathrm{OH}$ & 400 \\
\hline $\mathrm{CAH} 22$ & HMX-C & 40 & $15 \mathrm{M} \mathrm{NH}_{4} \mathrm{OH}$ & 400 \\
\hline CAH26 & $\mathrm{HMX}-\mathrm{C}$ & 80 & $1.5 \mathrm{M} \mathrm{NH}_{4} \mathrm{OH}$ & 800 \\
\hline $\mathrm{CAH} 27$ & LX-04 & 40 & $1.5 \mathrm{M} \mathrm{NH}_{4} \mathrm{OH}$ & 400 \\
\hline $\mathrm{CAH} 28$ & LX-04 & 40 & $1.5 \mathrm{M} \mathrm{NH}_{4} \mathrm{OH}$ & 400 \\
\hline $\mathrm{CAH} 29$ & PBX 9501 & 40 & $1.5 \mathrm{M} \mathrm{NH}_{4} \mathrm{OH}$ & 400 \\
\hline $\mathrm{CAH} 30$ & $\mathrm{HMX}-\mathrm{C}$ & 40 & $1.5 \mathrm{M} \mathrm{NH}_{4} \mathrm{OH}$ & 400 \\
\hline $\mathrm{CAH} 32$ & $\mathrm{HMX}-\mathrm{C}$ & 40 & $1.5 \mathrm{M} \mathrm{NaOH}$ & 400 \\
\hline CAH33 & $\mathrm{HMX}-\mathrm{C}$ & 80 & $6 \mathrm{M} \mathrm{NaOH}$ & 200 \\
\hline $\mathrm{CAH} 34$ & PBX 9404 & 40 & $3 \mathrm{M} \mathrm{NaOH}$ & 200 \\
\hline $\mathrm{CAH} 35$ & PBX 9404 & 23.6 & $3 \mathrm{M} \mathrm{NaOH}$ & 118 \\
\hline CAH36 & LX-04 & 40 & $3 \mathrm{M} \mathrm{NaOH}$ & 200 \\
\hline CAH37 & LX-10 & 3.1 & $3 \mathrm{M} \mathrm{NaOH}$ & 15 \\
\hline
\end{tabular}




\section{APPARATUS}

At the start of an experiment, we placed all reactants in a sealed volume contained in a Parr reaction vessel. Four process conditions-liquid temperature, gas pressure, stirrer speed, and elapsed time-are monitored continuously and recorded digitally using Labview software. A controller box interfaces the reaction vessel with the data recording system and provides automatic control of temperature and manual control of stirrer speed.

\section{The Reaction Vessel}

The reaction vessel is a Stirred Pressure Reactor, Model 4522M, manufactured by Parr Instrument Company. It is a cylindrical can made of 316 stainless steel; its internal depth is $10.5 \mathrm{in}$., and the internal diameter is 4 in. The available internal volume is $2000 \mathrm{~mL}$. Some of the internal space is occupied by intrusions from the lid, such as a cooling coil, a thermowell, and a dip tube for withdrawing liquid samples. The vessel is rated to $1900 \mathrm{psig}$ at $350^{\circ} \mathrm{C}$.

A gas-sampling, or vent, valve is attached to the lid. The vessel has a single stirrer shaft, which comes through the lid. The stirrer consists of two impellers on a common shaft and can be driven at a variable speed $(0$ to $700 \mathrm{rpm})$. The vessel contents are heated by conduction through the vessel side wall from an electrical heating jacket. This heating method provides a fairly constant heating rate independent of liquid level in the vessel. A serpentine cooling coil is mounted to the reactor lid or head. The cooling fluid was tap water. For early experiments, cooling water was not part of the temperature control scheme.

\section{Data Collection}

The continuous monitoring system, which samples process conditions every 5 seconds, consists of analog inputs for liquid temperature, gas pressure, and stirrer speed. The system then converts these inputs to digital signals, which are recorded by applying a Labview program. Typically, these three parameters are plotted against elapsed time to produce a chronogram. Elapsed time begins when the program is executed, which is approximately when the heater is first energized. Typically, if the experimenter manually changes a process condition (for example, by withdrawing a gas or liquid sample or by switching off the heater), he also switches off the stirrer momentarily to provide a fiducial marker for the event.

To monitor liquid temperature, the experimenter places two thermocouples, along with a small amount of silicon oil, in the thermowell. Temperature is accurate to $\pm 2^{\circ} \mathrm{C}$. One thermocouple supplies feedback to the controller; the other supplies input to the data acquisition system and a high-temperature limit switch. A pressure transducer (range from 0 to $2500 \mathrm{psig}$ ) mounted on the reactor head supplies input to the data acquisition system and a high-pressure-limit switch. Digital pressure data are accurate to $\pm 5 \mathrm{psig}$. We corrected all reported pressures (including those provided in the figures) to zero at ambient. An optical tachometer accurate to $\pm 5 \mathrm{rpm}$ monitors the speed of the stirrer shaft.

\section{Control Schemes}

Each experiment included a set point for liquid temperature and thermocouple feedback to a Watlow Series 945 controller. Most experiments included proportional-integral-derivative (PID) control. Except for the earliest experiments, energizing a solenoid valve enabled the flow of cooling water. We determined control constants by executing a typical experiment with the controller in "auto-tune" mode.

Experiments in which cooling water was not used exhibited an exotherm and temperatures sometimes from $20^{\circ} \mathrm{C}$ to $30^{\circ} \mathrm{C}$ higher than the set point. Figure 1 shows a typical chronogram of an experiment in which cooling water was not used. The temperature set point was $150^{\circ} \mathrm{C}$. After 30 $\mathrm{min}$, an exotherm to $178^{\circ} \mathrm{C}$ was observed. Another $40 \mathrm{~min}$ elapsed before the temperature stabilized at $150^{\circ} \mathrm{C}$. 
Figure 2 shows a chronogram typical of an experiment in which cooling water was used. This plot shows a gradual rise in pressure as time progresses beyond initial reaction rather than a fallingoff of the initial peak. Figure 2 also shows a series of small pressure spikes as the set-point temperature is approached. These spikes reflect the application of cooling water to control the exotherm. The temperature spikes are minimal compared with the pressure spikes, presumably a result of condensation of some vapors because a major portion of the cooling coil is in the head space of the vessel.

One early experiment without cooling water (CAH05) was conducted with a set point of $150^{\circ} \mathrm{C}$. The reactants, $80 \mathrm{~g}$ of HMX explosive powder and $800 \mathrm{~mL}$ of $1.5 \mathrm{M}$ ammonium hydroxide, were heated in a closed vessel. The peak temperature was $178^{\circ} \mathrm{C}$, and the peak pressure was $482 \mathrm{psig}$. Both of these peaks occurred before 40 minutes of elapsed time (Figure 3 ).

In contrast, experiments that included cooling water in a PID control loop never exceeded $151^{\circ} \mathrm{C}$ for a set point of $150^{\circ} \mathrm{C}$. These experiments were conducted with $40 \mathrm{~g}$ of $\mathrm{HMX}$ and $400 \mathrm{~mL}$ of 1.5 $\mathrm{M}$ ammonium hydroxide. The maximum pressure observed for these conditions (CAH17) was 239 psig, which occurred after more than 330 minutes of elapsed time. By 80 minutes of elapsed time the pressure exceeded $200 \mathrm{psig}$. The pressure tail continued to rise slowly until the experiment was stopped.

\section{REACTION PRODUCTS}

We routinely collected samples of the product liquid at the end of each experiment. In some of the early experiments, we also collected and analyzed samples of the product gases. At the beginning of the experiment, the vessel contained ambient atmosphere in the head space. We did not attempt to evacuate the vessel, by either purging or backfilling with inert gas. When the experiments were at set-point temperature and ambient temperature (after the experiment had cooled in the closed condition), we collected samples in evacuated $150-\mathrm{mL}$ bottles that were at ambient temperature to establish the product suite and fraction of each species. Because the aqueous product stream did not change character, the gaseous products were assumed to remain essentially constant as well. Because aqueous products were easier to collect and analyze, we did not collect gas samples in subsequent experiments.

\section{Liquid}

A conductivity detector enabled experimenters to use a Dionex ion chromatograph to perform quantitative analysis for inorganic and organic anions. Determinations of total carbon (TC) and total inorganic carbon (TIC) were performed by the combustion-infrared method. Total organic carbon (TOC) was then reflected as the difference between TC and TIC. Table 3 summarizes data from these analyses. Some samples were analyzed by two independent labs or analyzed at two

Table 3. Ion Chromatography and Carbon Analysis Results

\begin{tabular}{|c|c|c|c|c|c|c|c|c|c|c|}
\hline \multirow[b]{2}{*}{ Experiment } & \multicolumn{6}{|c|}{ Ion Concentration (mg/L) } & \multicolumn{3}{|c|}{ Carbon Content (mg/L) } & \multirow[b]{2}{*}{ Comments } \\
\hline & Nitrite & Nitrate & Formate & Acetate & Ammonium & $\begin{array}{l}\text { Methyl } \\
\text {-amine }\end{array}$ & $\begin{array}{l}\text { Total } \\
\text { Carbon } \\
\text { (TC) }\end{array}$ & $\begin{array}{l}\text { Organic } \\
\text { Carbon } \\
\text { (TOC) }\end{array}$ & $\begin{array}{c}\text { Inorganic } \\
\text { Carbon } \\
\text { (IC) }\end{array}$ & \\
\hline CAHOI & 1.212 & 372 & 16,326 & 195 & 13,804 & 1.140 & 15,396 & 14,222 & 1,174 & $85 \mathrm{~min}$ at $150^{\circ} \mathrm{C}$ \\
\hline $\mathrm{CAH} 02$ & 6,150 & 54 & 7,770 & 231 & 19,485 & 500 & 7,668 & 7,520 & 148 & Doubled volume of base \\
\hline $\mathrm{CAH} 03$ & 2,223 & 228 & 12.976 & 295 & 14,037 & 830 & 15,200 & 14,771 & 429 & Typical conditions \\
\hline CAH04 & 20,010 & 0 & 19.250 & 560 & NA & NA & 15.710 & 15,570 & 140 & Concentrated base $(15 \mathrm{M})$ \\
\hline $\mathrm{CAH17}$ & 284 & 466 & 13.619 & 0 & 18,324 & 1.612 & 13.920 & 11,240 & 2,680 & $308 \mathrm{~min}$ at $150^{\circ} \mathrm{C}$ \\
\hline CAH26 & 4.233 & 0 & 13.892 & 464 & 14,375 & 806 & 15.666 & 15.334 & 332 & Regulated at 80 to $85 \mathrm{psig}$ \\
\hline CAH33 & 81.750 & 0 & 84,550 & 6,600 & NA & NA & NA & NA & $\mathrm{NA}$ & $6 \mathrm{M} \mathrm{NaOH}, 1 / 4$ volume \\
\hline
\end{tabular}


different dilutions. For these samples, the average value is reported. Nuclear magnetic resonance (NMR) spectrometry helped to identify species.

We obtained an excellent carbon balance in experiment CAH26. Two methods were used to determine the amount of carbon present initially. In the first method, based on the weight of unrecovered HMX (79.82 g), 16,180 mg/L of carbon was converted to species other than HMX. In the second method, TC determination of the final liquid, all carbon from the reacted HMX is assumed to be still present in the liquid. This analysis indicated that there was $15,666 \mathrm{mg} / \mathrm{L}$ of carbon. This is $96.8 \%$ of all reacted HMX as determined by the first method.

Ion chromatography and quantitative NMR were used to determine the quantities of carbonbearing species in the final liquid. Ion chromatography indicated $3,705 \mathrm{mg} / \mathrm{L}$ of carbon in the formate ion, and quantitative NMR established the concentration ratio of formate to hexamine. We used this ratio to determine that the hexamine contained $12,189 \mathrm{mg} / \mathrm{L}$ of carbon. Combining the hexamine and formate yields a total of $15,894 \mathrm{mg} / \mathrm{L}$ of carbon in the aqueous product stream. This is $98 \%$ of the carbon in the reacted HMX as determined by the first method and $101 \%$ of the carbon found by TC determination in the second method.

\section{Gas}

Analysis of gas samples by gas chromatography (GC) revealed no carbon-bearing species such as carbon monoxide, carbon dioxide, and methane. Table 4 is a summary of the gas chromatography results. The analysis did not include ammonia. Approximately $50 \%$ of the product gas was nitrous oxide. The consumption of oxygen was observed but not investigated further.

We tried to determine the nitrogen balance of the system (liquid and gas). The partial pressures of diatomic nitrogen and nitrous oxide were determined by GC analysis. (We used the ideal gas law to calculate the nitrogen in the reactor head space at ambient pressure.) All the partial pressures in Table 4 were summed and subtracted from $100 \%$, and the difference was assumed to be ammonia. Ammonia in the liquid was determined by ion chromatography (IC). Approximately half the nitrogen appeared to be in the final gas and half in the final liquid. Although only $67 \%$ of the original nitrogen is accounted for, we believe that all nitrogen-bearing species are included. The balance might be improved by incorporating argon detection to determine nitrogen contribution from air, considering the solubility of pressurized nitrous oxide in the liquid, and analyzing for ammonia rather than assuming a mole fraction by difference.

\section{REACTION CONDITIONS}

Initial experiments were conducted at a temperature set point of $150^{\circ} \mathrm{C}$ in a closed system. We chose a reasonably high temperature for solubility reasons. Modeling indicates that the reaction of sodium hydroxide with HMX in an open system is mass-transfer-limited. ${ }^{3}$ The speed of reaction

Table 4. Gas Chromatography Results

\begin{tabular}{|c|c|c|c|c|c|}
\hline Experiment & $\begin{array}{c}\text { Partial } \\
\text { Pressure } \\
\text { Oxygen (torr) }\end{array}$ & $\begin{array}{c}\text { Partial } \\
\text { Pressure } \\
\text { Nitrogen } \\
\text { (torr) } \\
\end{array}$ & $\begin{array}{c}\text { Partial } \\
\text { Pressure } \\
\text { Nitrous Oxide } \\
\text { (torr) } \\
\end{array}$ & $\begin{array}{c}\text { Elapsed Time } \\
\text { When Sample } \\
\text { Was Taken } \\
\text { (min) }\end{array}$ & Comments \\
\hline CAHOI & 14 & 46.03 & 0 & 35 & $\begin{array}{l}\text { "Blank", no } \mathrm{HMX} \text { in } \\
\text { vessel, sampled at } \\
152^{\circ} \mathrm{C}\end{array}$ \\
\hline $\mathrm{CAHO3}$ & 1.4 & 31.3 & 46.4 & 87 & Sampled at $146^{\circ} \mathrm{C}$ \\
\hline $\mathrm{CAHO2}$ & 1.3 & 21.78 & 48.8 & 99 & $\begin{array}{l}20 \mathrm{~mL} \text { base per gram HMX, } \\
\text { sampled at } 148^{\circ} \mathrm{C}\end{array}$ \\
\hline CAHOI & trace & 26.98 & 46.6 & 113 & Sampled at $150^{\circ} \mathrm{C}$ \\
\hline CAHOI & trace & 28.8 & 49.4 & 173 & Sampled at $36^{\circ} \mathrm{C}$ \\
\hline $\mathrm{CAHI7}$ & 0 & 32.06 & 51.16 & 400 & Sampled at $24^{\circ} \mathrm{C}$ \\
\hline
\end{tabular}


depends largely on the solubility of the HMX in the aqueous, basic solution. This solubility has a strong dependence on temperature.

For all experiments except CAH26, the system remained closed so that the extent of the reaction could be estimated by monitoring pressure changes-we expected significant gas evolution. A closed system also helps establish maximum pressure levels; knowledge of such levels is useful in the design of safe vessels.

For most experiments, we chose the run time (experiment duration or "time at temperature") to ensure complete reaction so that end products could be established. Stirrer speed was maintained near $500 \mathrm{rpm}$ for all experiments except CAH35, in which there was no stirring.

\section{Effects of Reduced Temperature and Solvent}

Early experiments in a closed system resulted in pressures well over the 100-psig rating of largescale reaction vessels. Figure 3 shows the chronogram of such an experiment.

Because one approach to reducing the pressure is to reduce the temperature, we conducted CAH06 at a temperature set point of $130^{\circ} \mathrm{C}$. The maximum pressure in this experiment was $88 \mathrm{psig}$. Because cooling water was not part of the control loop, the temperature rose to $146^{\circ} \mathrm{C}$. The reactants were held at or above the set-point temperature for $54 \mathrm{~min}$. In previous experiments no solids remained after $30 \mathrm{~min}$ at or above $150^{\circ} \mathrm{C}$. However, in this experiment when the reaction vessel was opened, visual examination indicated that much of the original $20 \mathrm{~g}$ of $\mathrm{HMX}$ was still present. For the next experiment (CAH07), we closed the reaction vessel, reheated it to $130^{\circ} \mathrm{C}$, and held the reactants at or above the set-point temperature for $100 \mathrm{~min}$. We then opened the reactor and filtered the product liquid. Of the original quantity of solids, $3 \%$ was not consumed. The pressure in the head space was lower, as we had hoped it would be, but the reaction was also very slow.

Experiment CAHII included dimethylsulfoxide (DMSO) to enhance the solubility at the reduced temperature and thereby hasten the reaction. We dissolved $20 \mathrm{~g}$ of HMX in $50 \mathrm{~mL}$ of DMSO and added the solution to $200 \mathrm{~mL}$ of $1.5 \mathrm{M}$ ammonium hydroxide. After $20 \mathrm{~min}$ at $130^{\circ} \mathrm{C}$ or above, no recoverable solids remained. The maximum gas pressure was $121 \mathrm{psig}$, and the maximum temperature was $155^{\circ} \mathrm{C}$. The only new peak in the NMR analysis of the liquid was from DMSO. The results of this experiment support the theory of a solubility-limited reaction. However, because solvents complicate the waste stream, we tested another approach.

\section{Effects of Constant Reduced Pressure}

Another method for reducing pressure is simply to vent some of the gas through a pressure relief valve. The gas analysis performed on previous experiments showed that about $50 \%$ of the product gas is nitrous oxide. To prevent the escape of the reactant ammonia, operating at a pressure somewhat above the vapor pressure of aqueous ammonia is necessary. The proper combination of pressure and temperature should retain ammonia in the reactor and release the principal product gas, nitrous oxide. (A reflux condenser, if available, could accomplish the same purpose.)

The plot of pressure against temperature for several experiments, shown in Figure 4, helped establish an operating temperature. The experiment without explosive (CAH20) is referred to as a "blank." These experiments helped establish the pressure level produced by vapor pressure of the volatile reactants alone (no product gases). Plotting with data from several experiments and adding an error bar to the pressure in the "blank" experiment give some indication of the temperature at which the reaction begins to produce observable quantities of gas-even though the temperatures are not truly steady state. The data in Figure 4 are also consistent with the results of CAH06 already described. On the basis of the data in Figure 4, we chose a set-point temperature of $140^{\circ} \mathrm{C}$.

The pressure of the so-called blank experiment was approximately 60 psig at the non-steadystate temperature of $140^{\circ} \mathrm{C}$. Extrapolation of published vapor pressure data suggests a pressure of 70 to $75 \mathrm{psig}$ for a $1.45 \mathrm{M}$ solution at a steady-state temperature of $140^{\circ} \mathrm{C}$. Thus, an operating pressure between 80 and 85 psig seemed high enough to retain the ammonia while remaining safely below a typical vessel rating of 100 psig. 
We conducted experiment CAH26 at a temperature set point of $140^{\circ} \mathrm{C}$ with automatic PID control. We manually regulated the pressure between 80 and 85 psig and maintained the reactor near $140^{\circ} \mathrm{C}$ for $180 \mathrm{~min}$. Of the $80 \mathrm{~g}$ of $\mathrm{HMX}$ present at the beginning of the experiment, $99 \%$ was unrecovered and considered consumed in the reaction. The section on reaction products in the liquid phase described the carbon balance for this experiment, which successfully demonstrated the feasibility of operating in a pressure-relief mode at moderate pressures.

\section{Effects of Run-Time and Concentration}

A qualitative comparison of the results of NMR scans from experiments CAH03, CAH17, and CAH22 reveals the effects of run time and concentration on the final products. The NMR scan for CAH03, an early experiment run for $70 \mathrm{~min}$ near $150^{\circ} \mathrm{C}$ and using $1.5 \mathrm{M}$ ammonium hydroxide, clearly shows the principal peaks to be hexamine and formate.

We intentionally ran experiment CAH17 for an extended time to see whether the "rising tail" of pressure would level. We held the reactor near $150^{\circ} \mathrm{C}$ for $308 \mathrm{~min}$, again with $1.5 \mathrm{M}$ ammonium hydroxide. The product liquid was very dark brown at the end of the run. The NMR scan revealed no hexamine peak, and new peaks, believed to be associated with the formation of trimethylamine, did appear.

In experiment $\mathrm{CAH} 22$, conducted under conditions similar to those of $\mathrm{CAH} 17$ except that concentrated ammonium hydroxide $(15 \mathrm{M})$ was used, we held the reactor near $150^{\circ} \mathrm{C}$ for $340 \mathrm{~min}$. The NMR scan clearly showed the principal peaks to be hexamine and formate. The results of these three experiments suggest that excess ammonia prevents the breakdown of hexamine, even with prolonged time in the reactor.

\section{APPLICATION TO PBX MOLDING POWDERS}

Of primary interest to the U.S. Department of Energy weapons dismantlement program are three plastic-bonded explosives (PBXs): LX-04, PBX 9404, and PBX 9501. For each of these, we processed $40 \mathrm{~g}$ of molding powder at $150^{\circ} \mathrm{C}$ with $1.5 \mathrm{M}$ ammonium hydroxide. As shown in Table 5, each molding powder uses a different binder. For PBX 9404, the plasticizer is tris (2-chloroethyl) phosphate; for PBX 9501, the plasticizer is $50 / 50 \mathrm{wt} \%$ bis (2,2-dinitropropyl) acetal and bis $(2,2-$ dinitropropyl) formal.

Table 6 summarizes the results of these experiments. For LX-04, the percentage of solids consumed corresponds very closely with the percentage of HMX; for PBX 9501, it corresponds to the percentage of HMX and plasticizer; and for PBX 9404, it corresponds to the percentage of HMX,

Table 5. Molding Powder Compositions

\begin{tabular}{|c|c|c|c|c|}
\hline Molding Powder & Binder & $\begin{array}{l}\text { Proportion of } \\
\text { Binder (wt\%) }\end{array}$ & $\begin{array}{c}\text { Proportion of } \\
\text { HMX (wt\%) }\end{array}$ & $\begin{array}{l}\text { Proportion of } \\
\text { Plasticizer (wt\%) }\end{array}$ \\
\hline PBX 9404 & Nitro-cellulose & 3 & 94 & 3 \\
\hline LX-04 & Viton A & 15 & 85 & 0 \\
\hline PBX 9501 & Estane 5703 & 2.5 & 95 & 2.5 \\
\hline
\end{tabular}

Table 6. Summary of Experiments with PBX Molding Powders

\begin{tabular}{|c|c|c|c|c|}
\hline Molding Powder & Binder & $\begin{array}{l}\text { Proportion of } \\
\text { Binder (wt\%) }\end{array}$ & $\begin{array}{c}\text { Proportion of } \\
\text { HMX (wt\%) }\end{array}$ & $\begin{array}{l}\text { Proportion of } \\
\text { Plasticizer (wt\%) }\end{array}$ \\
\hline PBX 9404 & Nitro-cellulose & 3 & 94 & 3 \\
\hline LX-04 & Viton A & 15 & 85 & 0 \\
\hline PBX 9501 & Estane 5703 & 2.5 & 95 & 2.5 \\
\hline
\end{tabular}


plasticizer, and binder. The binder material for both LX-04 (viton) and PBX 9501 (estane) is insoluble in water and resistant to attack by base; however, the nitrocellulose from the PBX 9404 appears to be completely consumed in the reaction.

NMR spectrometry indicated that the aqueous products from experiments CAH21 (for PBX 9404) and CAH27 (for LX-04) were nearly identical and correspond to those achieved in long runtime experiments with HMX. The aqueous products from experiments $\mathrm{CAH} 28$ (for LX-04) and CAH29 (for PBX 9501) were also nearly identical to each other and correspond well with short run-time experiments with HMX. These experiments lead to two principal conclusions: these three different types of PBX molding powders can be processed successfully, and the principal product set (hexamine and formate) is essentially independent of the binders tested and is the same for HMX alone. Apparently, the quantities of any products from the small amount of non-HMX components present in PBX 9404 and PBX 9501 are too small to be detected by NMR

\section{A COMPARISON WITH "HOT" SODIUM HYDROXIDE}

The original intent of the ammonium hydroxide experiments was to compare their results with those of the sodium hydroxide experiments. The latter were typically conducted at ambient pressure near the boiling temperature of the solution (approximately $90^{\circ} \mathrm{C}$ in Los Alamos). We considered the need for a pressurized system to be a drawback of the ammonia process. As the work progressed, we began to wonder whether the sodium hydroxide process would be significantly enhanced at higher temperatures. If so, the value of a shorter process might exceed the modest bother of using a closed system. We conducted a few experiments to explore this possibility.

Table 7 summarizes the conditions and some of the results of these experiments. Figures 5 through 10 show the chronograms of all the experiments except CAH37, which was conducted in a smaller vessel without data acquisition or automatic temperature control systems.

We conducted the first two experiments (CAH30 and CAH32) for the purpose of making a direct comparison-the only difference between the two experiments was the type of base. We used the same molarity for each solution; however, from a purely scientific point of view, the concentration of hydroxide ion might have been a better parameter to hold constant because the disassociation differs depending on whether the hydroxide ion is with ammonium or sodium in solution. From a practical point of view, the conclusion that sodium hydroxide provides a faster process is still apparent. A comparison of the chronogram of the $15 \mathrm{M}$ ammonium hydroxide experiment (Figure 11) with the chronogram of the $6 \mathrm{M}$ sodium hydroxide experiment (Figure 7) validates this conclusion. For the same temperature set point $\left(150^{\circ} \mathrm{C}\right)$ and temperature control scheme (PID with cooling water), the latter experiment had an uncontrolled exotherm compared with the former experiment.

Although the earlier work of Spontarelli et al. ${ }^{2}$ showed significantly reduced effectiveness at higher concentrations of sodium hydroxide (up to $5 \mathrm{M}$ ) when experiments were conducted at $85^{\circ} \mathrm{C}$, this does not appear to be the case when experiments are conducted at higher temperatures. The experiment with $6 \mathrm{M}$ sodium hydroxide was so effective-it resulted in an uncontrolled exothermthat subsequent experiments were conducted with $3 \mathrm{M}$ solutions. These experiments were quite effective as well. Most of the experiments listed in Table 7 were conducted at $150^{\circ} \mathrm{C}$ with $5 \mathrm{~mL}$ of $3 \mathrm{M}$ solution per gram of explosive rather than $10 \mathrm{~mL}$ of $1.5 \mathrm{M}$ solution per gram of explosive. By doubling the concentration and halving the volume of solution, we reduced the volume of waste generated by the process by $50 \%$.

Experiments with molding powders of plastic-bonded explosives demonstrated that the HMX is still accessible and can be successfully destroyed. The LX-04 molding powder (15\% viton binder) left a residue of dark-brown, lightweight, spongy granules. A die-pressed cylinder of PBX 9404 $(23.6 \mathrm{~g})$ was destroyed within $7 \mathrm{~min}$ at temperature. The solution only partially covered the consolidated piece, and we did not stir it.

By contrast, experiment CAH37, with a smaller, die-pressed cylinder of LX-10 (94.5\% HMX, $5.5 \%$ Viton $\mathrm{A}$ ), was largely unsuccessful until $15 \mathrm{~mL}$ of ethanol was added to the solution. At the 
Table 7. Summary of Experiments to Evaluate $\mathrm{NaOH}$ at Elevated Temperature

\begin{tabular}{|c|c|c|c|c|c|c|}
\hline Experiment & Explosive & Base & $\begin{array}{c}\text { Set-point } \\
\text { Temperature } \\
\left({ }^{\circ} \mathrm{C}\right)\end{array}$ & $\begin{array}{c}\text { Time at } \\
\text { Temperature } \\
\text { (min) }\end{array}$ & $\begin{array}{c}\begin{array}{c}\text { Solids } \\
\text { Consumed } \\
(\%)\end{array} \\
\end{array}$ & Comments \\
\hline САН30 & $40 \mathrm{~g} \mathrm{HMX}$ & $\begin{array}{c}1.5 \mathrm{M} \\
\mathrm{NH}_{4} \mathrm{OH} \\
400 \mathrm{~mL}\end{array}$ & 150 & 5 & 67 & \\
\hline $\mathrm{CAH} 32$ & $40 \mathrm{~g} \mathrm{HMX}$ & $\begin{array}{c}1.5 \mathrm{M} \mathrm{NaOH}, \\
400 \mathrm{~mL}\end{array}$ & 142 & 5 & 99.9 & \\
\hline CAH33 & $80 \mathrm{~g} \mathrm{HMX}$ & $\begin{array}{c}6 \mathrm{M} \mathrm{NaOH}, \\
200 \mathrm{~mL}\end{array}$ & 150 & 9 & 99.7 & $\begin{array}{l}\text { Pressure rose } \\
379 \text { psig in } 30 \mathrm{~s} \\
\text { (maximum } \\
\text { pressure was } \\
431 \text { psig). } \\
\text { Temperature rose } \\
59^{\circ} \mathrm{C} \text { in } 42 \mathrm{~s} \\
\text { (maximum } \\
\text { temperature was } \\
174^{\circ} \mathrm{C} \text { ). }\end{array}$ \\
\hline$\overline{\mathrm{CAH} 34}$ & $\begin{array}{l}40 \mathrm{~g} \mathrm{PBX} 9404 \\
\text { (molding powder) }\end{array}$ & $\begin{array}{l}3 \mathrm{M} \mathrm{NaOH}, \\
200 \mathrm{~mL}\end{array}$ & 150 & 8 & 99.6 & \\
\hline CAH35 & $\begin{array}{l}23.6 \mathrm{~g} \text { PBX } 9404 \\
\text { (consolidated } \\
\text { piece) }\end{array}$ & $\begin{array}{c}3 \mathrm{M} \mathrm{NaOH}, \\
118 \mathrm{~mL}\end{array}$ & 150 & 7 & 100 & $\begin{array}{l}\text { Piece was } 1 \text { in. in } \\
\text { diam and } 1 \text { in. } \\
\text { high, only } 75 \% \\
\text { immersed in liquid. } \\
\text { Solution was not } \\
\text { stirred. }\end{array}$ \\
\hline $\mathrm{CAH} 36$ & $\begin{array}{c}40 \mathrm{~g} \mathrm{LX}-04 \\
\text { (molding powder) }\end{array}$ & $\begin{array}{l}3 \mathrm{M} \mathrm{NaOH}, \\
200 \mathrm{~mL}\end{array}$ & 150 & 8 & 82.7 & \\
\hline CAH37 & $\begin{array}{c}3.1 \mathrm{~g} \mathrm{LX}-10 \\
\text { (consolidated } \\
\text { piece) }\end{array}$ & $\begin{array}{c}3 \mathrm{M} \mathrm{NaOH}, \\
15.5 \mathrm{~mL}\end{array}$ & 150 & $\begin{array}{c}5 \\
\text { (over } 130^{\circ} \mathrm{C} \\
\text { for } 20 \mathrm{~min} \text { ) }\end{array}$ & 23.5 & $\begin{array}{l}\text { Piece was } 0.5 \text { inch } \\
\text { diam, } 0.5 \text { in. high, } \\
\text { only } 50 \% \\
\text { immersed in liquid. } \\
\text { Experiment was } \\
\text { conducted in a } \\
\text { l00-mL vessel with } \\
\text { manual } \\
\text { temperature } \\
\text { control. Solution } \\
\text { was not stirred. }\end{array}$ \\
\hline
\end{tabular}

end of the initial trial summarized in Table 7, we cooked this consolidated piece $(3.1 \mathrm{~g})$ for over an hour at $150^{\circ} \mathrm{C}$ without significant destruction. After we added ethanol (diluting the base to $1.5 \mathrm{M}$ ) and cooked the piece for another hour at the same temperature, the HMX was $98 \%$ destroyed.

By analogy with experiment CAH26, we believe that "hot" sodium hydroxide experiments would be successful when conducted in a vessel with a pressure relief valve set for 80 to 85 psig. The sodium hydroxide solution is less likely to lose volatile reactants than the ammonium hydroxide solution, which was shown to be successful in CAH26.

\section{CONCLUSION}

The results of numerous experiments with ammonium hydroxide and up to $80 \mathrm{~g}$ of HMX corroborate the conclusions of earlier work at a smaller scale. Thus, ammonium hydroxide can be used successfully to convert HMX to nonexplosive, water-soluble products. The resulting aqueous product stream has two principal species, hexamine and formate; and the principal product gases are nitrous oxide, nitrogen, and ammonia. 
These experiments extend the knowledge of the process involved: the reaction proceeds much faster when HMX solubility is increased by adding a stable solvent (DMSO) or applying a higher temperature, and HMX in plastic-bonded molding powders is accessible and consumed without a significant increase in time. However, consolidated pieces with a viton binder require a viton solvent (ethanol) to be successful.

Application of the process in a "production" environment is clearly feasible. One experiment showed that the reaction with ammonium hydroxide may be carried to completion in a vessel with a moderate pressure rating by venting the gas through a pressure relief valve set for 80 to 85 psig. Other experiments demonstrated that a significant reduction in processing time can be achieved by using sodium hydroxide in a pressure reactor at $150^{\circ} \mathrm{C}$. Further, reactions using higher concentrations of sodium hydroxide $(3 \mathrm{M})$ are practical at elevated temperature and result in a reduced volume of the waste stream.

The ammonium hydroxide process creates a clean, well-defined waste stream, and the concentrated sodium hydroxide process at elevated temperature results in shorter processing times and a reduced volume of waste.

\section{ACKNOWLEDGMENT}

A particular thanks to Jose Archuleta and Rhonda McInroy for their sample analysis.

\section{REFERENCES}

1. G. A. Buntain, J. A. Sanchez, T. Spontarelli, and T. M. Benziger, Destruction of Waste Energetic Materials Using Base Hydrolysis, Los Alamos National Laboratory document LA-UR 93-1527 (May 1993).

2. T. Spontarelli, G. A. Buntain, R. L. Flesner, J. A. Sanchez, and P. J. Unkefer, An Engineered System Using Base Hydrolysis for Complete Disposal of Energetic Materials, Los Alamos National Laboratory document LA-UR 94-444 (March 1994).

3. J. F. Kramer, R. Flesner, and T. Spontarelli (Explosives Technology Group, Los Alamos National Laboratory), "Remediation of Energetic Materials Using Base Hydrolysis," presented at Joint Explosives Processing Committee Meeting, Amarillo, Texas, October 1994. 


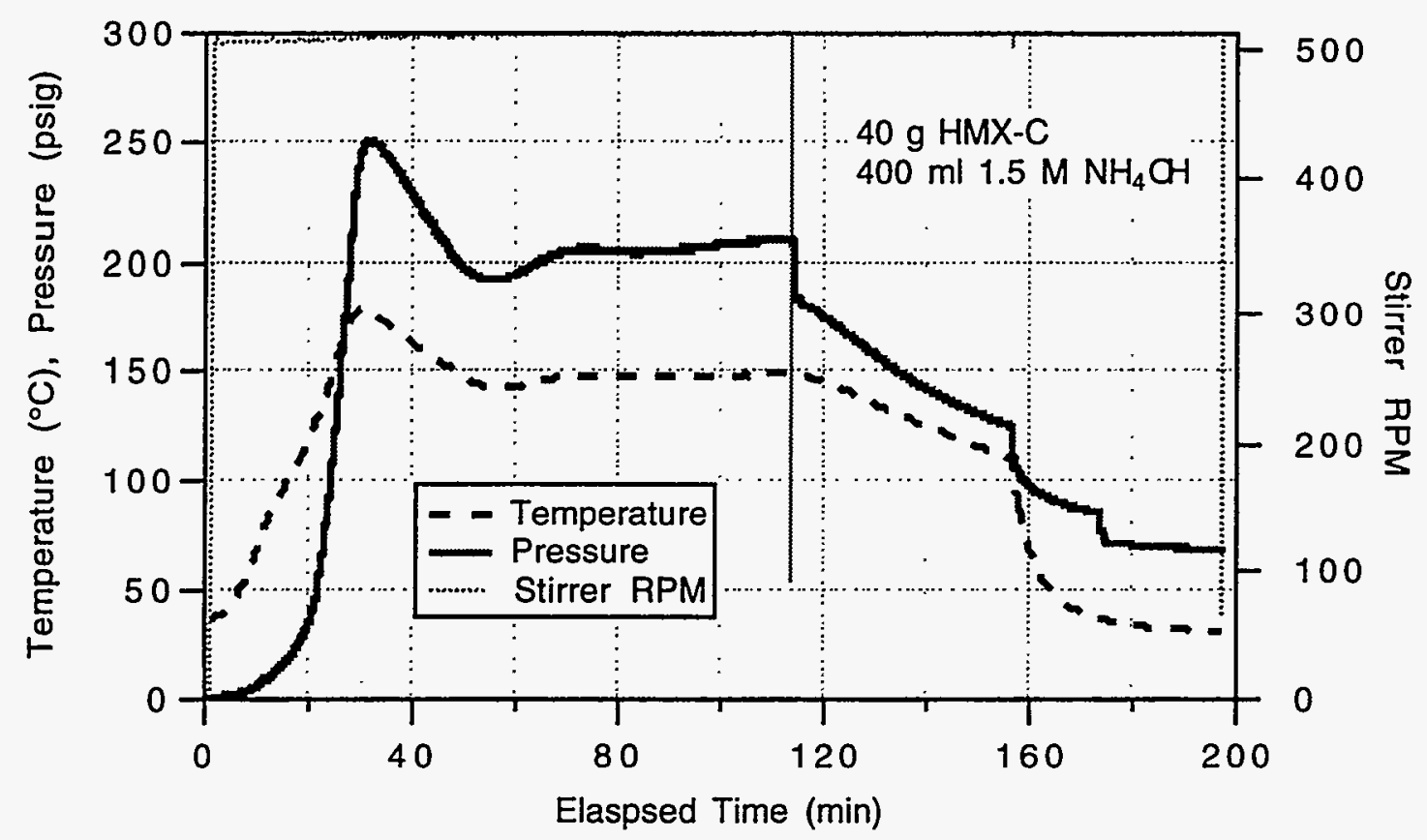

Figure 1. Chronogram without cooling water in the control loop (CAH01).

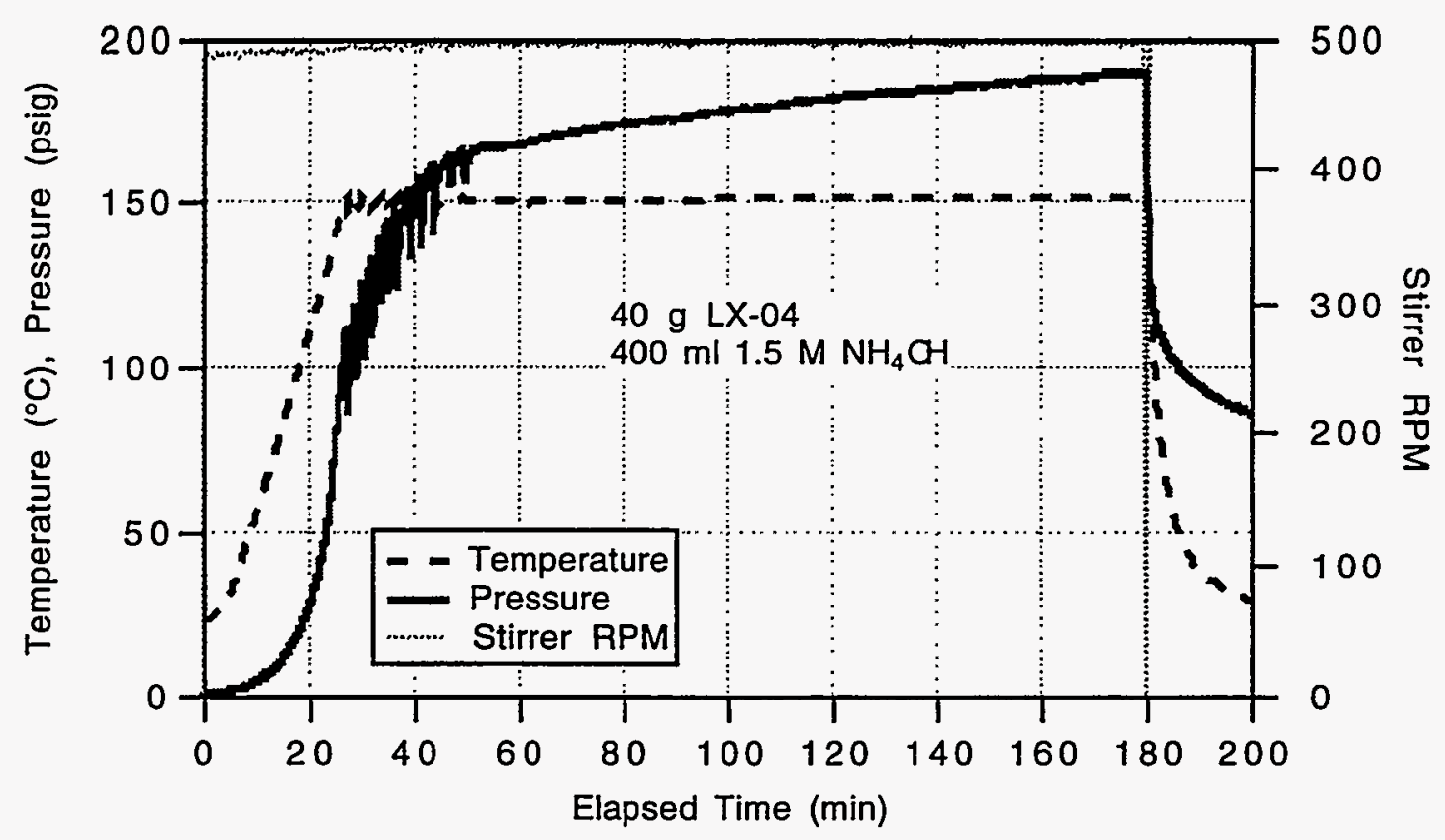

Figure 2. Chronogram with cooling water in the control loop (CAH28). 


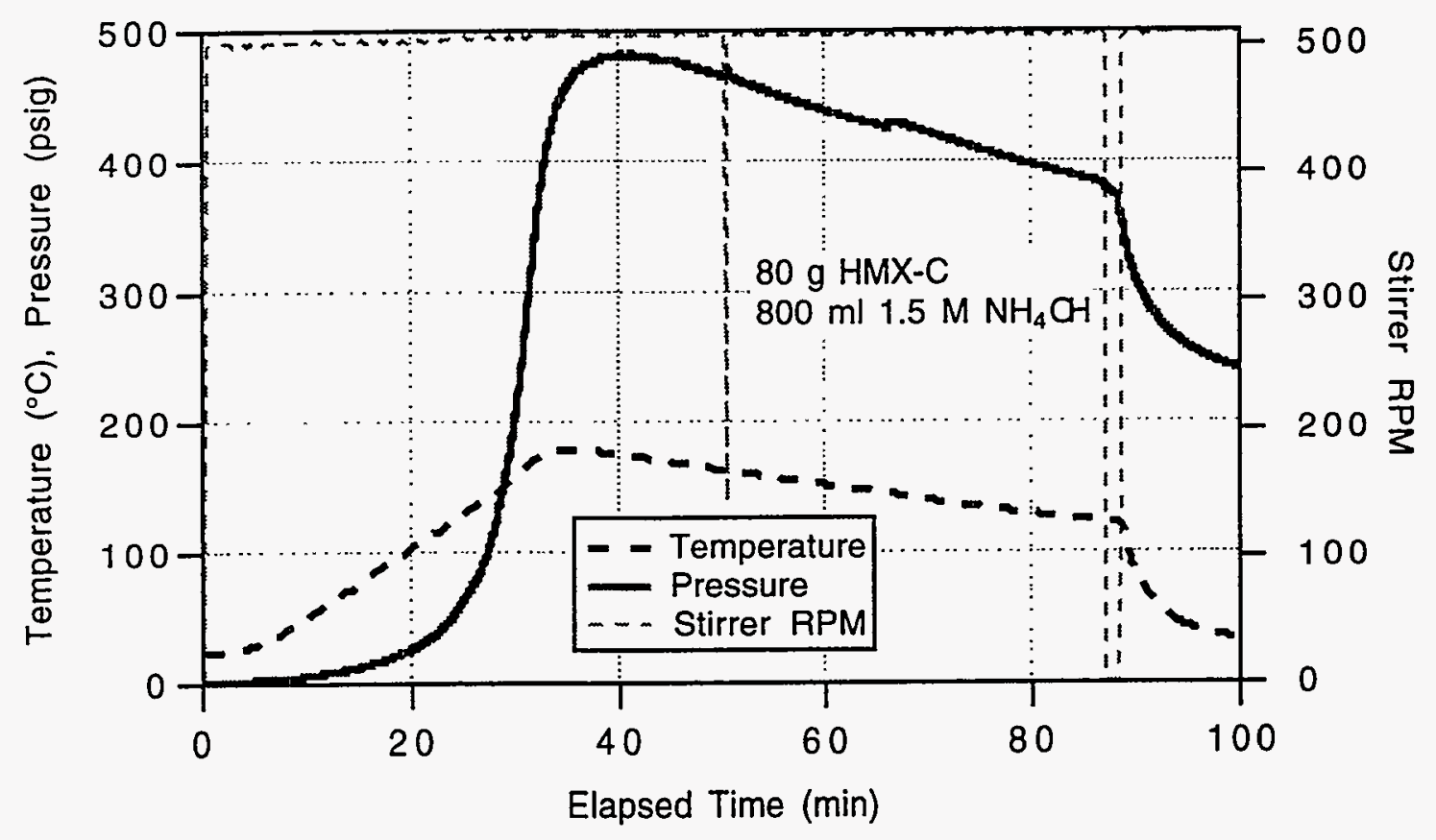

Figure 3. Chronogram of experiment CAH05.

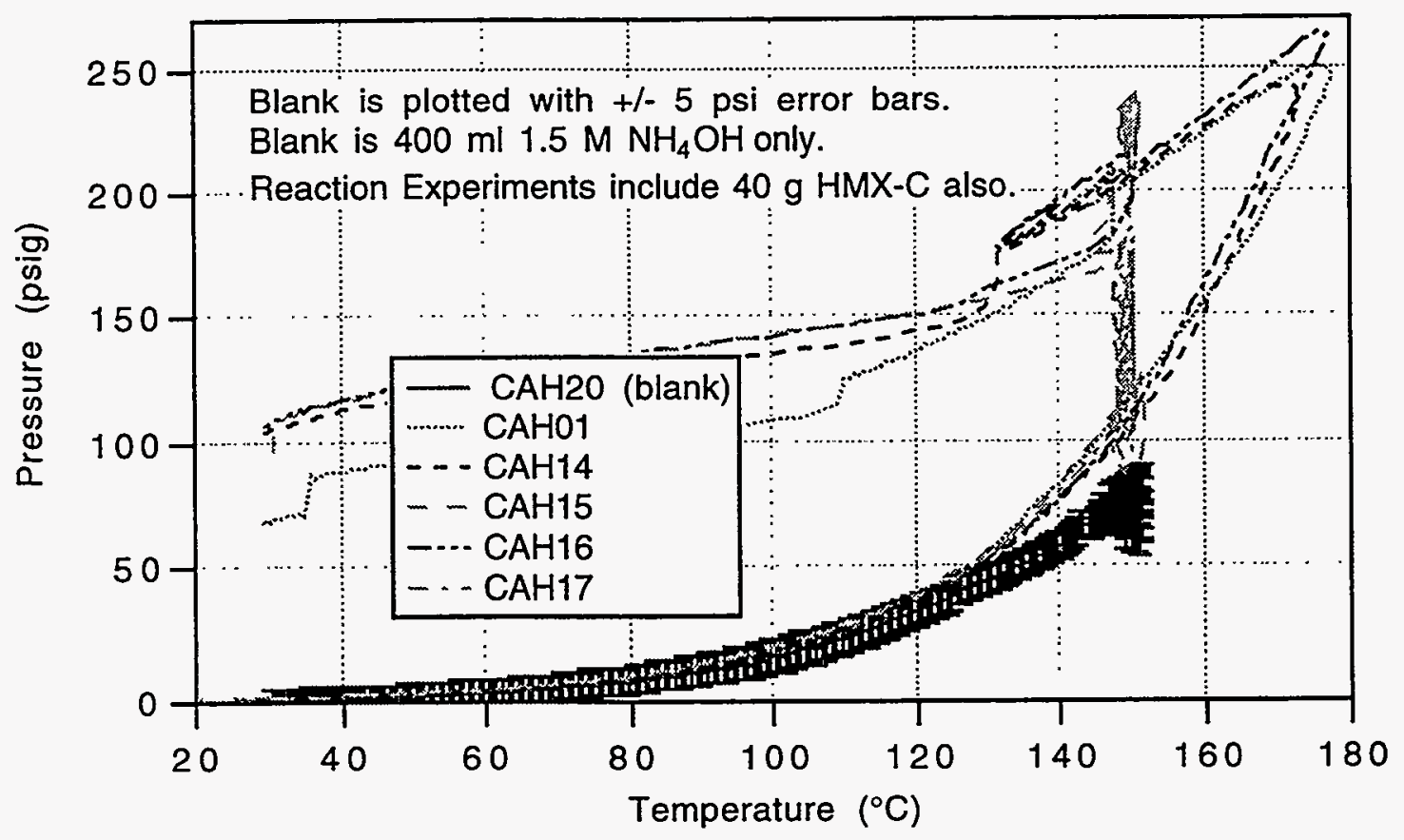

Figure 4. A "blank" compared with several reaction experiments. 


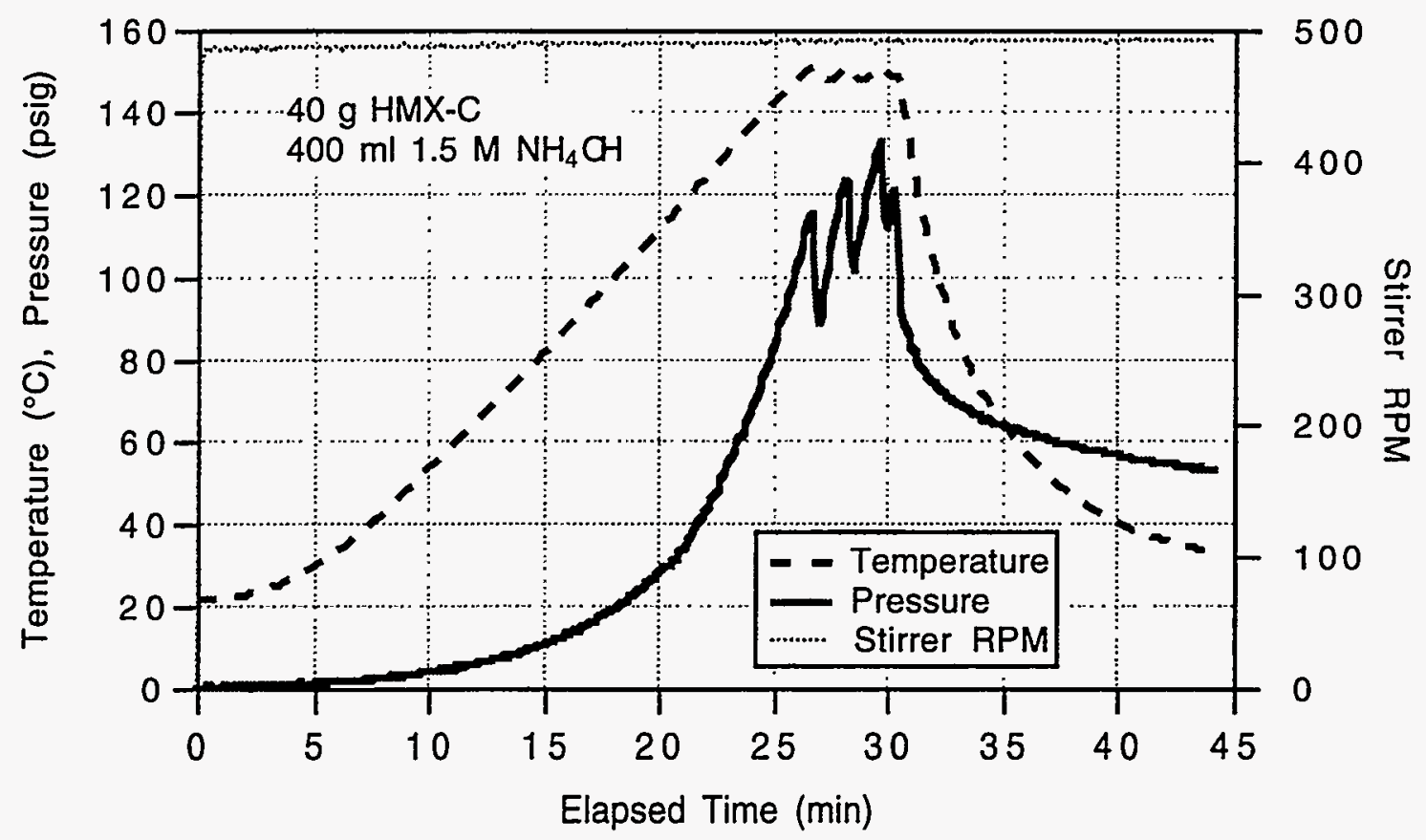

Figure 5. Chronogram of baseline ammonium hydroxide experiment ( $\mathrm{CAH} 30)$.

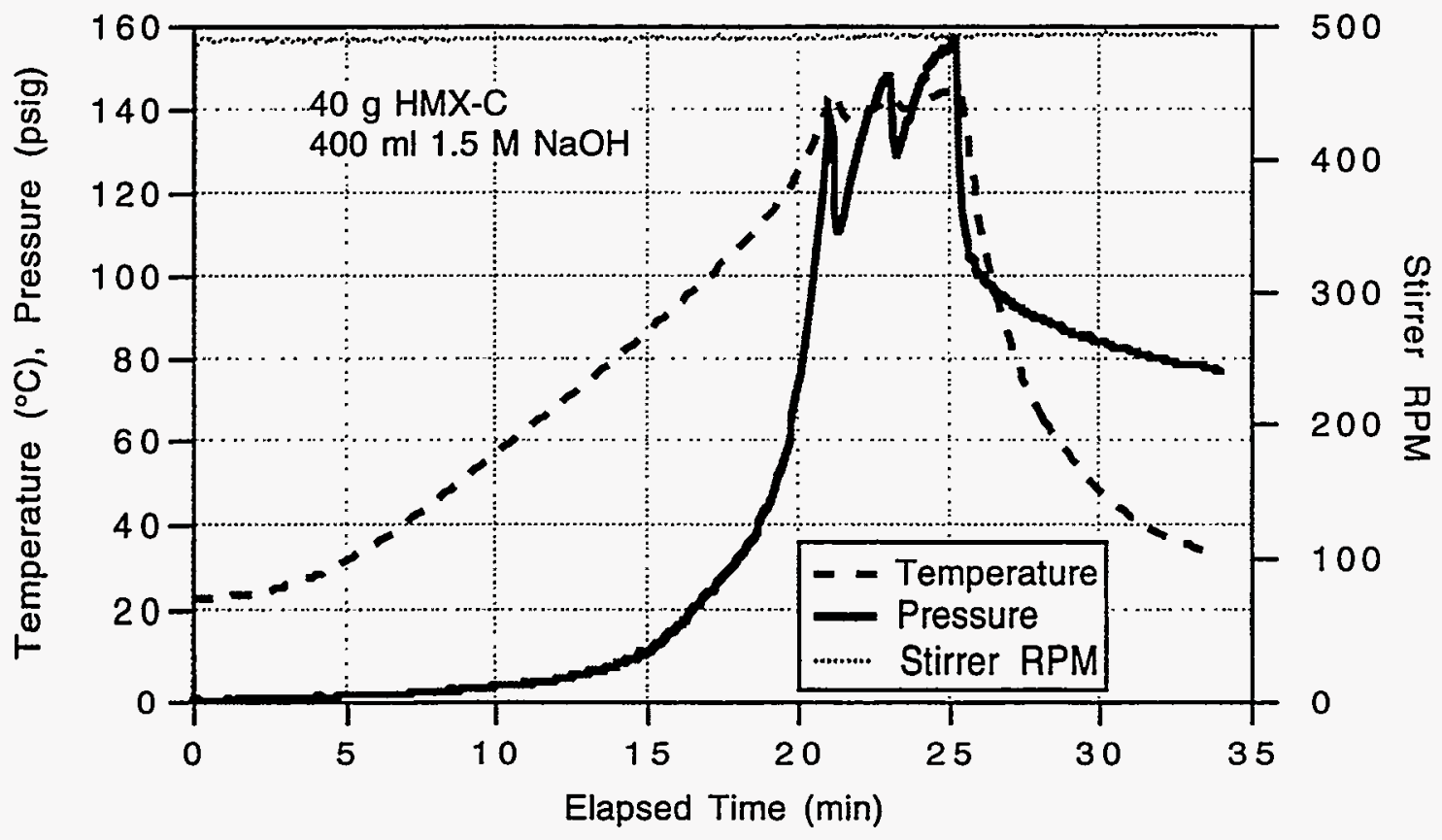

Figure 6. Chronogram of baseline sodium hydroxide experiment (CAH32). 


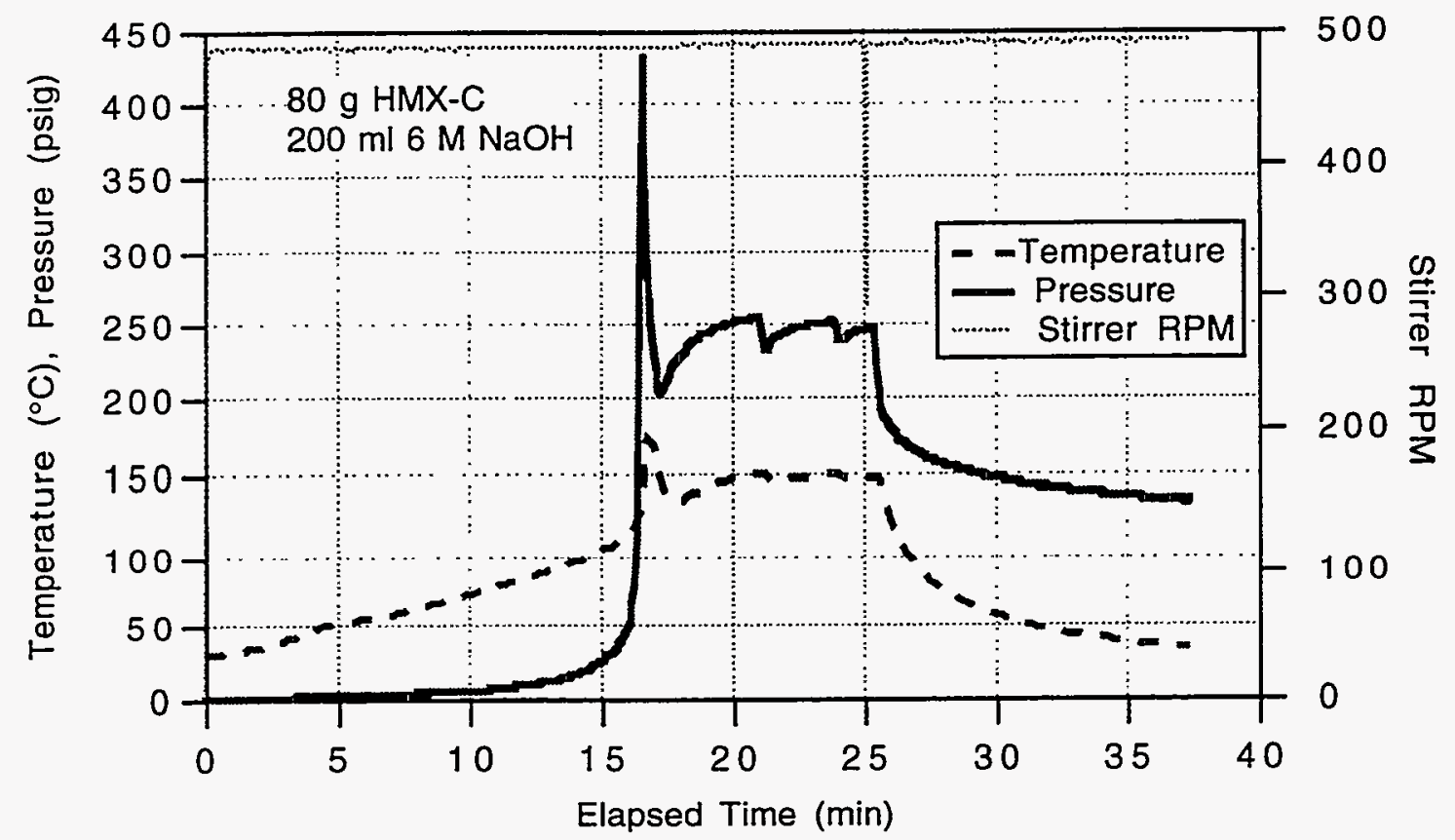

Figure 7. Chronogram of $6 \mathrm{M}$ sodium hydroxide experiment (CAH33).

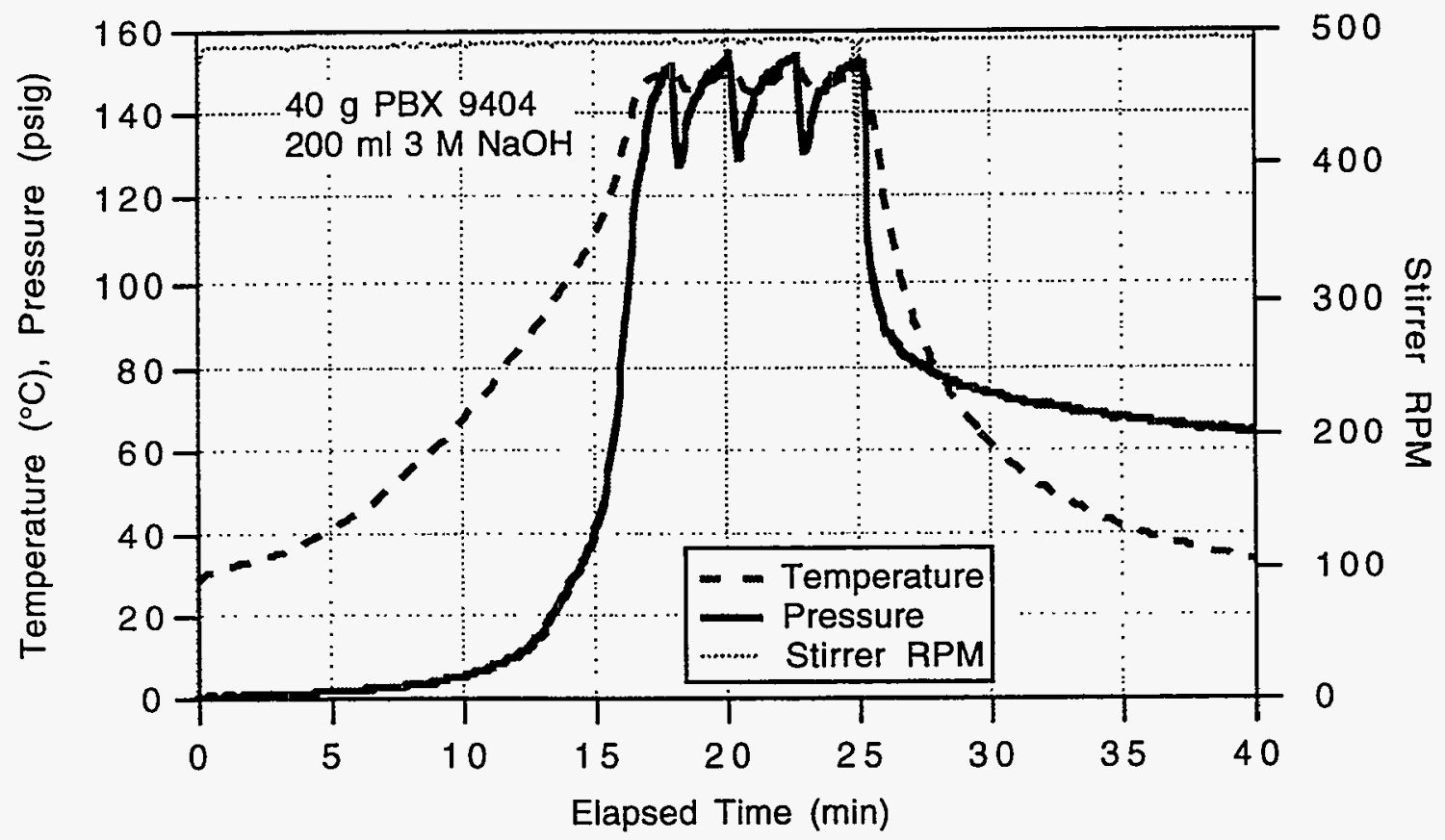

Figure 8. Chronogram of PBX 9404 molding powder experiment (CAH34). 


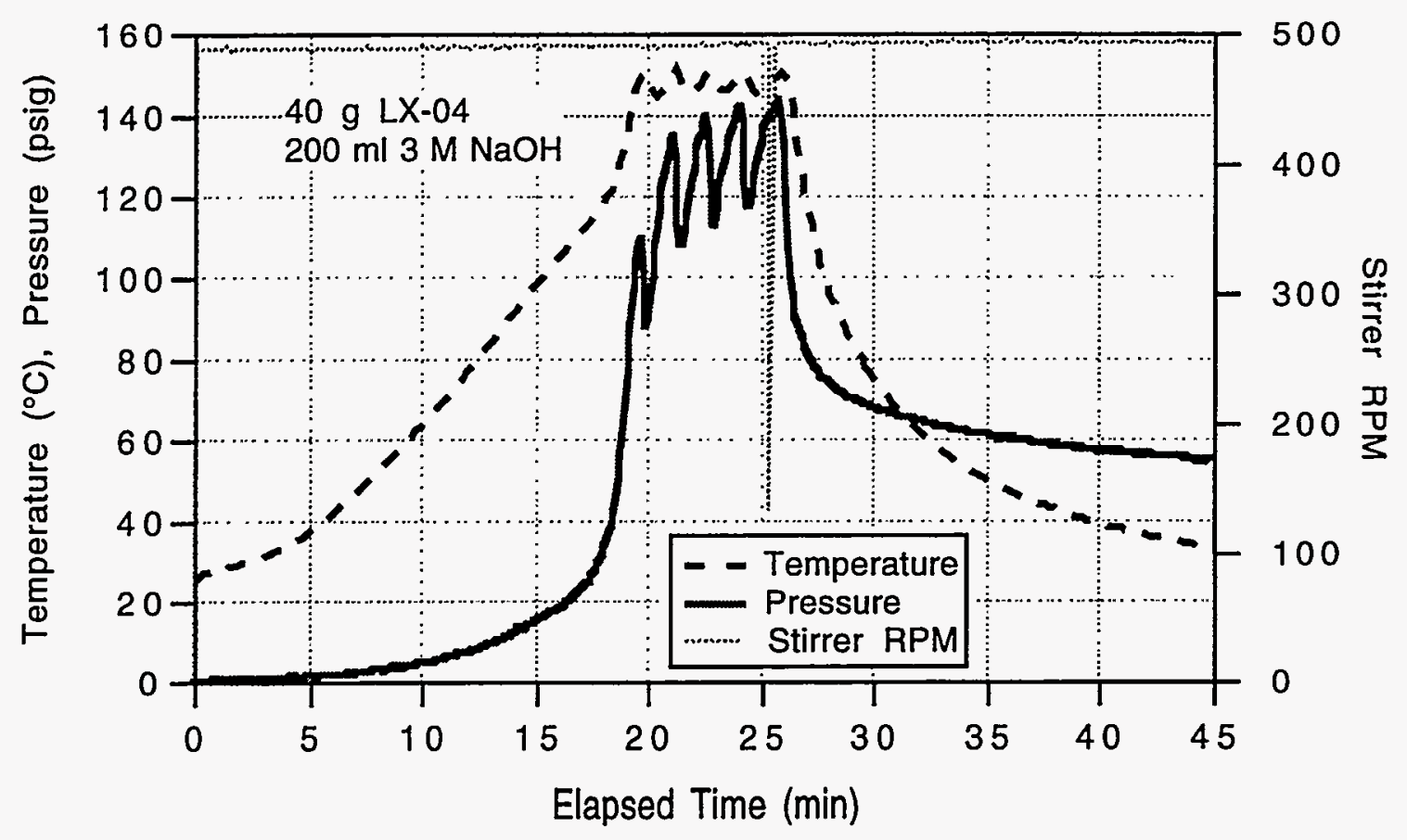

Figure 9. Chronogram of LX-04 molding powder experiment (CAH36).

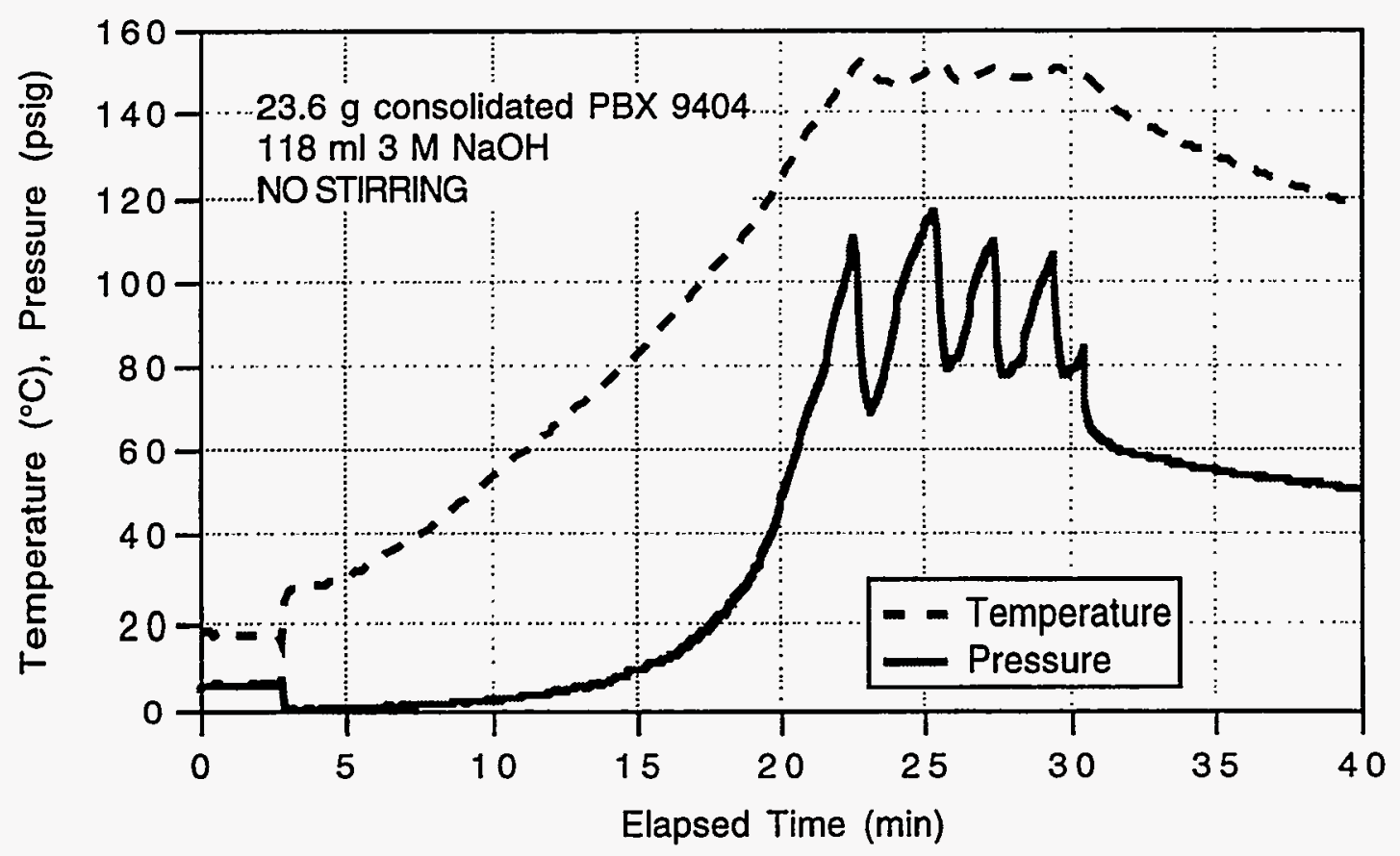

Figure 10. Chronogram of PBX 9404 consolidated-piece experiment (CAH35). 


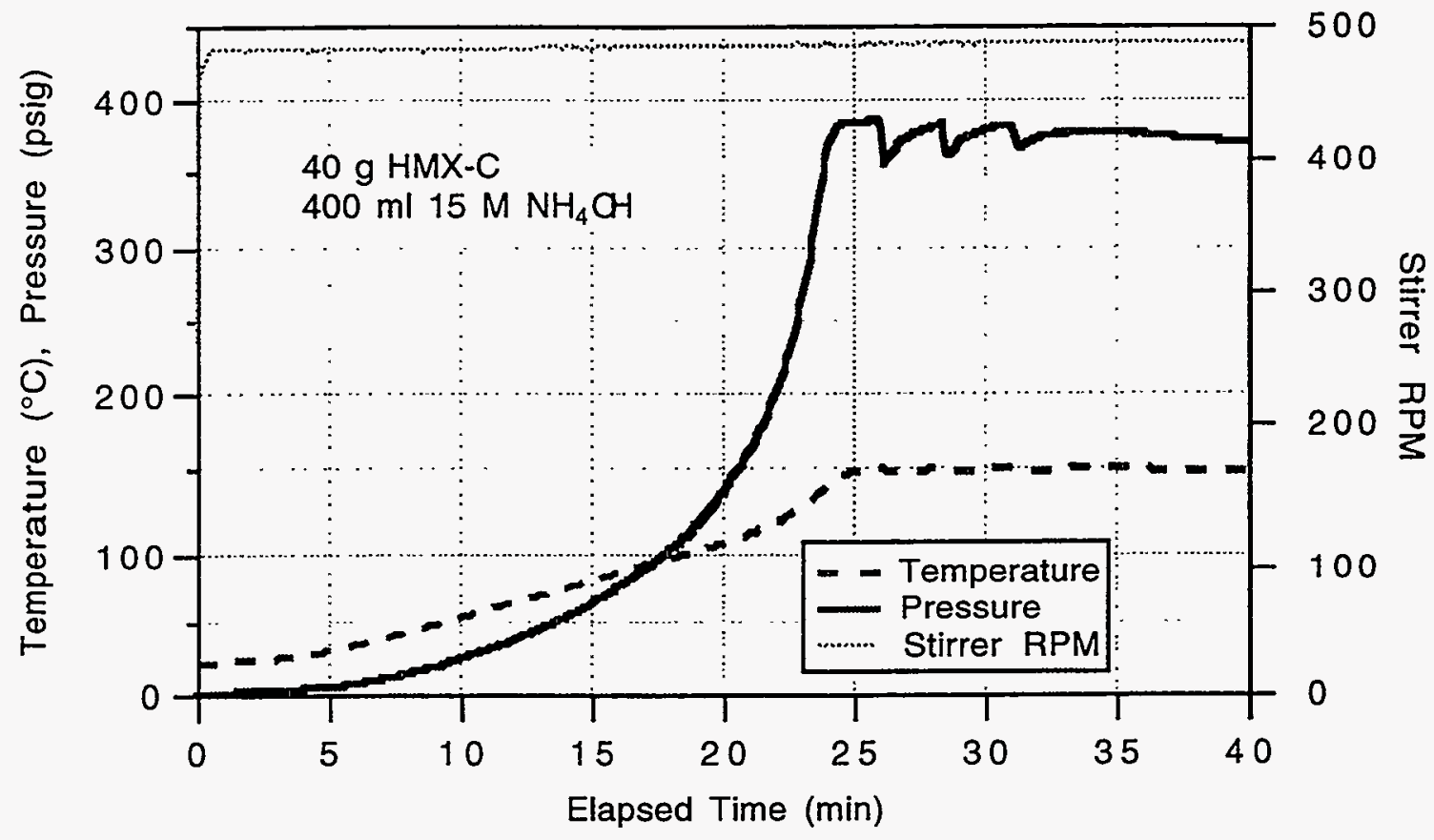

Figure 11. Chronogram of $15 \mathrm{M}$ ammonium hydroxide experiment (CAH22). 